\title{
The Relationship between Teachers' Fostering Relevance Behavior and Middle School Students' Cognitive Engagement in Mathematics
}

\author{
Bellita N. Pratiwi*, Linda Primana \\ Faculty of Psychology, University of Indonesia, Depok, Indonesia \\ *E-mail: bellitapratiwi@gmail.com
}

\begin{abstract}
Indonesia's long-desired quality education has not yet attained as the national quality indicators consistently show students' low achievement, as the result of their poor understanding of school subjects. It happens because of the frequent use of rote learning strategy, instead of deep level of cognitive engagement. Teacher support, in the form of autonomy-enhancing behaviors, is regarded as one of the most important environmental factors that influence student engagement. This study aims to investigate the relationship between teachers' fostering relevance behavior, a type of autonomy-enhancing behavior, and middle school students' cognitive engagement in mathematics. Fostering relevance behavior and cognitive engagement was measured by Autonomy Affecting Behavior scale (Assor, Kaplan, \& Roth, 2002) and Learning Strategies Scales from Motivated Strategies for Learning Questionnaire (MSLQ) (Pintrich \& De Groot, 1990). Pearson correlation showed that there was a significant positive relationship between perceived teachers' fostering relevance behavior and students' cognitive engagement $(r=0.34$; $\mathrm{p}<0.01)$.
\end{abstract}

Keywords: autonomy-enhancing behavior, cognitive engagement, fostering relevance behavior, mathematics, middle school student

\section{Introduction}

School is expected to empower students with knowledge and skills necessary for their optimal participation in modern societies (Act No. 20 of 2003 article 3; OECD, 2014). Indonesia's Ministry of National Education Regulation No. 22 of 2006 for example, states that the purpose of mathematics education provision is to make students understand mathematical concepts, such as geometry, statistics, and algebra, and also able to apply these concepts in solving real-life problems.

Unfortunately, - that particular objective of mathematics education seems to have not yet accomplished -, as Indonesian students repetitively occupy the bottom positions in mathematics section of international assessments, such as TIMMS (Trends in International Mathematics and Science Study and PISA (Programme for International Student Assessment) (Baswedan, 2014). Those assessments are usually used as national education's quality indicator (Hogan, Rahim, Chan, Kwek, \& Towndrow, 2012; Pranoto, in Kurniati, 2013; OECD, 2014).

The low achievement of Indonesia students in mathematics shows the inadequacy of their comprehension of the subject. This condition can be attributed to students' tendency to employ shallow learning strategies rather than deep learning strategies (Fredricks, Blumenfeld, \& Paris, 2004). Previous research (Ravindran, Greene, \& DeBacker, 2005) found that student who employs deep learning strategies would try to connect the incoming information with existing knowledge, thus creating a more complex knowledge structure, different to shallow learners. The absence of this knowledge structure would make - application of the knowledge to real life problems becomes difficult (Dole \& Sinatra, 1998; Hogan et al., 2012). 
Students would be able to achieve an integrated knowledge structure when they are cognitively engaged (Corno \& Mandinach, 1983; Fredricks et al., 2004; Hogan, et al., 2012; Pintrich \& Schrauben, 1992). Cognitive engagement is defined as psychological investment in learning, which involves cognitive strategy use and self-regulation (Fredricks, Blumenfeld, Friedel, \& Paris, 2005; Fredricks, McColskey, Meli, Mordica, Montrosse, \& Mooney, 2011; Pintrich \& De Groot, 1990).

Previous studies about cognitive engagement of middle school students showed interesting results. While some findings have shown that students' brain capacity to become cognitively engaged is increasing in their early adolescence (Keating, 2004; Mahatmya, Lohman, Matjasko, \& Farb, 2012; Santrock, 2011), some other findings showed that students' engagement would drop dramatically as they enter middle school (Eccles, Midgefield, \& Wigfield, 1993; Opdenakker, Maulana, \& Den Brok, 2012). This dramatic drop is particularly worrying, as evidence showed that engagement will become relatively stable after middle school (Janosz, Archambault, Morizot, \& Pagani, 2008). Thus, when students have low cognitive engagement in a particular subject throughout middle school, their engagement will likely stay low after that. As for implication, it will be hard for them to create a more complex knowledge structure regarding that subject. This contradiction indicates that environmental factors might have an important role as much as, or maybe more than, biological factors. According to Fredricks et al., (2004), there are four environmental factors that can influence the cognitive engagement, namely peers, classroom structure, task characteristics, and teacher support. Among those factors, teacher support is deemed as the most fundamental factor in promoting student engagement (Pianta, Hamre \& Allen, 2012). There are several forms of teachers support. The most crucial one in promoting cognitive engagement is fostering relevance behavior (Assor, Kaplan, \& Roth, 2002). Assor et al. (2002) stated that fostering relevance behavior involves teachers' attempt to help students to experience the learning process as relevant to and supportive of their self-determined interests, goals, and values. However, the study conducted by Assor et al. (2002) did not examine teacher support in specific classroom context, whereas other research shows that both teacher support and student cognitive engagement will vary from one subject matter to another (Marks, 2000; Roth \& Weinstock, 2013). Thus, it is important to decide the specific subject on which the study will be conducted. For this study, we would focus on mathematics as subject.

Mathematics consists of propositions asserted on the basis of reason alone, which then realized in mathematical symbols (Ernest, 2004). This certain nature of mathematics gives it an important role in developing students' reasoning ability, improving students' understanding of other related subjects, and developing adequate decision-making ability. These significant roles - make this subject important. Many countries even place it as a compulsory lesson for their students (Ernest, 2004; Leon, Medina-Garrido, \& Núñez, 2016). However, the same nature of this subject is also the reason why many students consider mathematics as a difficult subject to comprehend, unrelated to anything, and thus not useful for their everyday life (Ernest, 2004; Orthner, Jonessanpei, Rose, Mercado, \& Akos, 2010). This kind of thinking can make the students feel reluctant to engage further in their study - (Ernest, 2004; Orthner et al., 2010).

Moreover, in Indonesia context, mathematics teaching is usually delivered with lecture methods (Maulana, Opdenakker, Den Brok, \& Bosker, 2011). - In mathematics classes utilizing that kind of teaching, teacher support for students' needs for autonomy is usually minimal. Consequently, the students may become unengaged in their learning (Reeve \& Assor, 2011). To encourage engagement in such unattractive but important class, the teacher needs to explain why the class activities are worth their attention and effort. In other words, they need to exert their fostering relevance behavior (Reeve \& Assor, 2011).

The present study was designed to examine the relationship between teachers' fostering relevance behavior and middle school students' cognitive engagement in mathematics. Furthermore, this study also examined the relationship between fostering relevance behavior and two dimensions of cognitive engagement, namely cognitive strategy use and selfregulation.

\section{Methods}

Sample. Participants of this study were 232 middle school students from - Jakarta, Indonesia. Using a convenience sampling, most of the participants are within age range of $13-14$ years old (84.1\%).

Research Design. This study used is the nonexperimental retrospective study design. We examined an existing situation without waiting for 
another situation to emerge in the future without manipulating any of the variables (Kumar, 1999).

Instrument and Measurement. Students' perception of teacher's fostering relevance behavior was measured by Fostering Understanding and Interest subscale, which is part of Autonomy Affecting Behavior Scale (Assor, Kaplan, \& Roth, 2002). This instrument has been adapted to Indonesian language. It consists of four items and has a good internal consistency $(\alpha=0.78)$. Items were rated on a four-point Likert scale.

Cognitive engagement was measured by Learning Strategies Scales from Motivated Strategies for Learning Questionnaire (MSLQ) (Pintrich \& De Groot, 1990). - This scale has also been adapted to Indonesian language. It consists of two subscales, namely cognitive strategy use (13 items, $\alpha=0.825$ ) and self-regulation ( 9 items, $\alpha=0.726$ ). The original measurement uses 7-Likert scale format. However, in order to avoid central tendency (Borgers, \& Sikkel, 2004), this study simplified the rating into four-point Likert scale format $(1=$ not at all true of me to $4=$ very true of me).

Procedure. - Participants were recruited from three public schools in Jakarta after getting permission. The questionnaire was administered in the class at the agreed time and took around 30 minutes to complete. Students were free to ask any question regarding the questionnaire's items and to return the questionnaire if they did not wish to participate.

\section{Results}

Table 1 presents the descriptive statistics of variables that were examined in this study.

Table 1.

Descriptive statistics of research variables

\begin{tabular}{lcccc}
\hline \multicolumn{1}{c}{ Variable } & Min. & Max & Mean & SD \\
\hline $\begin{array}{l}\text { Fostering } \\
\text { Relevance } \\
\text { Behavior }\end{array}$ & 4.00 & 16.00 & 11.21 & 2.50 \\
$\begin{array}{l}\text { Cognitive } \\
\text { Engagement }\end{array}$ & 2.00 & 3.64 & 2.92 & 0.29 \\
$\begin{array}{l}\text { Cognitive } \\
\text { Strategy Use }\end{array}$ & 2.00 & 3.69 & 3.00 & 0.32 \\
Self-Regulation & 1.78 & 3.89 & 2.81 & 0.35 \\
\hline
\end{tabular}

As shown in Table 1, students' perception of teachers fostering relevance behavior was quite high $(M=11.21, \quad S D=2.50)$. It - means participants perceived their math teacher has already shown fostering relevance behavior often. Consecutively, participants of this study also showed high cognitive engagement $(M=2.92, S D=0.29)$, cognitive strategy use $(M=3.00, \quad S D=0.32), \quad$ and self-regulation $(M=2.81, S D=0.35)$. Thus, in general, it could be concluded that participants were cognitively engaged in math lessons and often used both self-regulation and cognitive strategy.

Table 2.

Results of Pearson Correlation among Research Variables

\begin{tabular}{llll}
\hline & $\begin{array}{l}\text { Cognitive } \\
\text { Engagement }\end{array}$ & $\begin{array}{l}\text { Cognitive } \\
\text { Strategy } \\
\text { Use }\end{array}$ & $\begin{array}{l}\text { Self- } \\
\text { Regulation }\end{array}$ \\
\hline $\begin{array}{l}\text { Fostering } \\
\text { Relevance }\end{array}$ & $0.34^{* *}$ & $0.30^{* *}$ & $0.29^{* *}$ \\
Age & $0.12^{*}$ & 0.03 & $0.20^{* *}$ \\
\hline
\end{tabular}

Note. ${ }^{* *}=\mathrm{p}<0.01$ (2-tailed); $*=\mathrm{p}<0.05$ (2-tailed)

The result of Pearson correlation in table 2 shows that there was significant positive correlation between teachers' fostering relevance behavior and students' cognitive engagement $(r=0.34 ; p<0.01)$. This result support this study's hypothesis about the relationship between variables. Higher fostering relevance behavior conducted by teacher would be followed by higher cognitive engagement by students. In addition, from the correlation coefficient, it can be said that $11.28 \%$ of variance in students' cognitive engagement could be explained teacher's fostering relevance behavior $\left(R^{2}=0.11\right)$.

The Pearson correlation analysis also showed that there was a significant and positive relationship between teacher's fostering relevance behavior and students' cognitive strategy use $(r=0.30 ; p<0.01)$. There was also a significant and positive relationship between teacher's fostering relevance behavior and students' self-regulation $(r=0.29 ; p<0.01)$. Consequently, when teacher's fostering relevance behavior increase, students cognitive strategy use and self-regulation would also increase.

In addition, we also conducted an analysis to examine the relationship between age and cognitive engagement. The result indicated that there were positive and significant correlation between age with cognitive engagement $(r=0.12, p<0.05)$ and selfregulation $(r=0.20, p<0.01)$. - On the other hand, there was no significant correlation between age and students' cognitive strategy use $(r=0,031 ; p>0,05)$. 


\section{Discussion \& Conclusion}

Discussion. The main finding in this study has confirmed that students' cognitive engagement increases as they perceive their teachers have shown fostering relevance behaviors. This finding is consistent with the previous study conducted by Assor et al. (2002). It also verifies that teacher support is indeed important factor in promoting student's engagement (Pianta et al., 2012).

The finding indicates that students' self-regulation and cognitive strategy use would increase as their perception of teachers' fostering relevance behavior increases. These results support Reeve and Assor (2011)'s opinion that mathematics teachers need to apply fostering relevance behaviors in order to encourage their students' engagement, especially in challenging subject like mathematics. However, as these findings were only applied to mathematics class, it will be interesting to conduct the study in another school subject. It will also be noteworthy if the future research conducted in experimental design. Aside from a firmer conclusion on the effect of teacher's fostering relevance behavior on students' cognitive engagement, this kind of design would make researcher able to compare the effect of teachers' fostering relevance behavior among conditions of factors.

However, result had shown that the correlation between fostering relevance behavior and cognitive engagement was not too strong. Further study could be conducted to see if other factors, such as peers and class structure, could explain students' cognitive engagement. Moreover, although quite a lot of previous research findings showed the benefit of students' autonomy support, study about autonomy-enhancing behavior needs to be conducted more (Roth \& Weinstock, 2013), specifically in the form of fostering relevance behavior.

Additionally, this study showed that students' cognitive engagement increases with age, albeit to a lesser extent. Thus, this evidence supports previous studies by Keating (2004) and Mahatmya et al. (2012), which stated the similar results. Meanwhile, even though students' self-regulation increases with age, their cognitive strategy does not have any relationship with age. Future research on the influence of age or brain maturation to cognitive engagement with longitudinal design will likely give a more accurate explanation.
Conclusions. The present study aimed to attest the relationship between teachers' fostering relevance behavior and middle school students' cognitive engagement in mathematics., Evidence showed that there was a positive and significant correlation between the two variables. Additionally, the findings have also shown that teachers' fostering relevance behavior related to two dimensions of cognitive engagement, namely cognitive strategy use and selfregulation. However, it must be borne in mind that this study is a correlational study. Hence, further research is important to prove whether fostering relevance behavior cause cognitive engagement or not and if it is, how big the effect is. Lastly, as this study was conducted solely in mathematics class, future research should be done in another class subject's context.

\section{References}

Assor, A., Kaplan, H., \& Roth, G. (2002). Choice is good, but relevance is excellent: Autonomy enhancing and suppressing teaching behaviors predicting students' engagement in schoolwork. British Journal of Educational Psychology, 27, 261-278.

Baswedan, A. R. (2014). Gawat darurat pendidikan Indonesia (Emergency State of Education in Indonesia). Kementerian Pendidikan dan Kebudayaan Republik Indonesia (Indonesia Ministry of Education and Culture). Accessed from https://www.republika.co.id/files/kemendikbud/PaparanMenteri-Kadisdik-141201-Low-v.0.pdf.

Borgers, N., Hox, J., \& Sikkel, D. (2004). Response effects in surveys on children and adolescents: The effect of number of response options, negative wording, and neutral mid-point. Quality \& Quantity, 38, 17-33.

Corno, L., \& Mandinach, E. B. (1983). The role of cognitive engagement in classroom learning and motivation. Educational Psychologist, 18, 88-108.

Dole, J. A. \& Sinatra, G. M. (1998). Reconceptualizing change in the cognitive construction of knowledge. Educational Psychologist, 33 (2/3), 109-128.

Eccles, J. S., Midgefield, C., \& Wigfield, A. (1993). Development during adolescence: The impact of stageenvironment fit on young adolescents' experiences in schools and in families. American Psychologist, 48, 90101

Ernest, P. (2004). The Philosophy of Mathematics Education. London: Taylor \& Francis Group.

Fredricks, J. A., Blumenfeld, P. C., Friedel, J., \& Paris, A. (2005). School engagement. In K. A. Moore and L. Lippman (Ed.), Conceptualizing and measuring indicators of positive development: What do children need to flourish? New York: Kluwer Academic/Plenum Press. 
Fredricks, J. A., Blumenfeld, P. C., \& Paris, A. H. (2004). School engagement: Potential of the concept, state of the evidence. Review of Educational Research 74 (1), 59109.

Fredricks, J. A. \& McColskey, W. (2012). The measurement of student engagement: A comparative analysis of various methods and student self-report instruments. In S.L. Christenson, A.L. Reschly, C. Wylie (Eds.). Handbook of Research on Student Engagement (763-781). New York: Springer.

Fredricks, J., McColskey, W., Meli, J., Mordica, J., Montrosse, B., \& Mooney, K. (2010). Measuring student engagement in upper elementary through high school: A description of 21 instruments. Department of Education, Institute of Education Sciences, National Center for Education Evaluation and Regional Assistance, Regional Educational Laboratory Southeast. Retrieved from http://ies.ed.gov/ncee/edlabs

Hogan, D., Rahim, R.A., Chan, M., Kwek, D., Towndrow, P. (2012). Understanding classroom talk in secondary three mathematics classes in Singapore. In B. Kaur \& T.L. Loh (Ed.), Reasoning, Communication and Connections in Mathematics: Yearbook 2012, Association of Mathematics Educators (pg. 169-194). Singapura: World Scientific.

Janosz, M., Archambault, I., Morizot, J., \& Pagani, L. S. (2008). School engagement trajectories and their differential predictive relations to dropout. Journal of Social Issues, 64, 21-40.

Keating, D. P. (2004). Cognitive and brain development. In R. M. Lerner \& L. Steinberg (Ed.), Handbook of adolescent psychology (2nd ed., pg. 45-84). New York: Wiley.

Kumar, R. (1999). Research Methodology. London: Sage.

Kurniati, D. (2013). Despite being ranked as the happiest, Indonesian students score poorly in PISA tests. The Establishment Post. Accessed from http://www.establishmentpost.com/despite-being-rankedas-the-happiest-indonesian-students-scores-poorly-inpisa-tests/\#ixzz3SCwiw49y.

Leon J, Medina-Garrido E and Núñez JL. (2017). Teaching quality in math class: the development of a scale and the analysis of its relationship with engagement and achievement. Front. Psychol. 8(895). doi: 10.3389/fpsyg.2017.00895.

Mahatmya, D., Lohman, B. J., Matjasko, J. L., \& Farb, A. F. (2012). Engagement across developmental periods. Dalam S.L. Christenson, A.L. Reschly, C. Wylie (Ed.). Handbook of Research on Student Engagement (45-63). New York: Springer.

Marks, H.M. (2000). Student engagement in instructional activity: Patterns in the elementary, middle, and high school years. American Educational Research Journal, 37 (1), 153-184.

Maulana, R., Opdenakker, M-C., Den Brok, P., Bosker, R. J. (2012). Teacher-student interpersonal behavior in secondary mathematics classes in Indonesia.
International Journal of Science and Mathematics Education, 10, 21 - 47

Meece, J. L., Blumenfeld, P. C., \& Hoyle, R. H. (1988). Students' goal orientations and cognitive engagement in classroom activities. Journal of Educational Psychology, $80,514-523$

Opdenakker, M.-C., Maulana, R., \& Den Den Brok, P. (2012). Teacher-student interpersonal relationships and academic motivation within one school year: Developmental changes and linkage. School Effectiveness and School Improvement, 23 95-119.

Organisation for Economic Co-operation and Development (2014). PISA 2012 Results. Accessed from http://www.oecd.org/pisa/keyfindings/pisa-2012-resultsoverview.pdf

Orthner, D. K., Jonessanpei, H., Rose, R., Mercado, M., \& Akos, P. (2010). Careerstart: A middle grades strategy for promoting student school engagement and academic success. Studia Universitatis Babeş-Bolyai, Sociologia, 1 , 137-153.

Pianta, R.C., Hamre, B.K., \& Allen, J.P. (2012). Teacherstudent relationships and engagement: Conceptualizing, measuring, and improving the capacity of classroom interactions. In S.L. Christenson, A.L. Reschly, \& C. Wylie (Ed.), Handbook of Student Engagement (pg. 365386). New York: Springer.

Peraturan Menteri Pendidikan Nasional (The Ministry of National Education Regulation) No. 22 Year 2006 tentang Standar Isi untuk Satuan Pendidikan Dasar dan Menengah (Content Standard of Element of Education in Elementary and Middle School). Accessed from http://jdih.kemdikbud.go.id/asbodoku/media/peruu/perme n_tahun2006_nomor22.pdf

Pintrich, P.R. \& De Groot, E.V. (1990). Motivational and selfregulated learning components of classroom academic performance. Journal of Educational Psychology 82(1) $33-40$.

Pintrich, P. R., \& Schrauben, B. (1992). Students' motivational beliefs and their cognitive engagement in classroom tasks. In D. Schunk \& J. Meece (Ed.), Student perceptions in the classroom: Causes and consequences (149-183). Hillsdale: Lawrence Erlbaum Associates.

Pintrich, P.R., Smith, D.A.F., Garcia, T, McKeachie, W.J. (1991). A Manual for the Use of the Motivated Strategies for Learning Questionnaire (MSLQ). Ann Arbor, MI: University of Michigan, National Center for Research to Improve Postsecondary Teaching and Learning.

Ravindran, B., Greene, B. A., \& DeBacker T. K. (2005). Predicting preservice teachers' cognitive engagement with goals and epistemological beliefs. The Journal of Educational Research, 98 (4), 222-232.

Reeve, J. \& Assor, A. (2011). Do social institutions necessarily suppress individuals' need for autonomy? The possibility of schools as autonomy-promoting contexts across the globe. In V. I. Chirkov, R. M. Ryan, \& K. M. Sheldon 
(Ed.). Human Autonomy in Cross-Cultural Context (111132). New York: Springer.

Roth, G., \& Weinstock, M. (2013). Teachers' epistemological beliefs as an antecedent of autonomy-supportive teaching. Motivation \& Emotion, 37, 402-412.

Santrock, J.W. (2011). Educational Psychology, $5^{\text {th }}$ ed. New York: McGraw-Hill Companies, Inc.

Skinner, E. A. \& Belmont, M. B. (1993). Motivation in the classroom: Reciprocal effects of teacher behavior and student engagement across the school year. Journal of Educational Psychology, 85 (4), 571-581.

Turner, J.C., Meyer, D.K., Cox, K.E., Logan, C., DiCintio, M., \& Thomas, C. T. (1998). Creating contexts for involvement in mathematics. Journal of Educational Psychology, 90, 730-745.

Undang-Undang Republik Indonesia (Indonesia Legislation) No. 20 Year 2003 Tentang Sistem Pendidikan Nasional (National Education System). Accessed from http://kemenag.go.id/file/dokumen/UU2003.pdf

Wigfield, A., Eccles, J.S., Fredricks, J.A. Simpkins, S., Roeser, R.W. \& Schiefele, U. (2015). Development of achievement motivation and engagement. In M.E. Lamb \& R.M. Lerner (Ed.). Handbook of Child Psychology and Developmental Science, $7^{\text {th }}$ ed. (657-700). New Jersey: John Wiley \& Sons, Inc. 